\title{
首条横跨南海古扩张脊超深水电磁测量成功完成
}

李福元, 高姘 ${ }^{*}$

中国地质调查局广州海洋地质调查局, 广州 510700

* 联系人, E-mail: dabeidou@126.com

\section{The first ultra deep water electromagnetic survey across the paleo spreading ridge of the South China Sea has been successfully completed}

Fuyuan Li \& Yan Gao*

Guangzhou Marine Geological Survey, China Geological Survey, Guangzhou 510700, China

* Corresponding author, E-mail: dabeidou@126.com

doi: 10.1360/TB-2020-1077

2020年7 8月, 中国地质调查局广州海洋地质调查局 (以下简称广海局)利用与中国地质大学(北京)联合研制的 海底大地电磁仪器系统(OBEM-III), 部署“海洋地质四号”
船成功完成国内首条横跨南海古扩张脊的超深水海洋大 地电磁调查. 此次调查测线长度约为 $260 \mathrm{~km}$, 平均水深为 $4100 \mathrm{~m}$ ，是国内目前规模最大、作业水深最深的海洋大 (a)
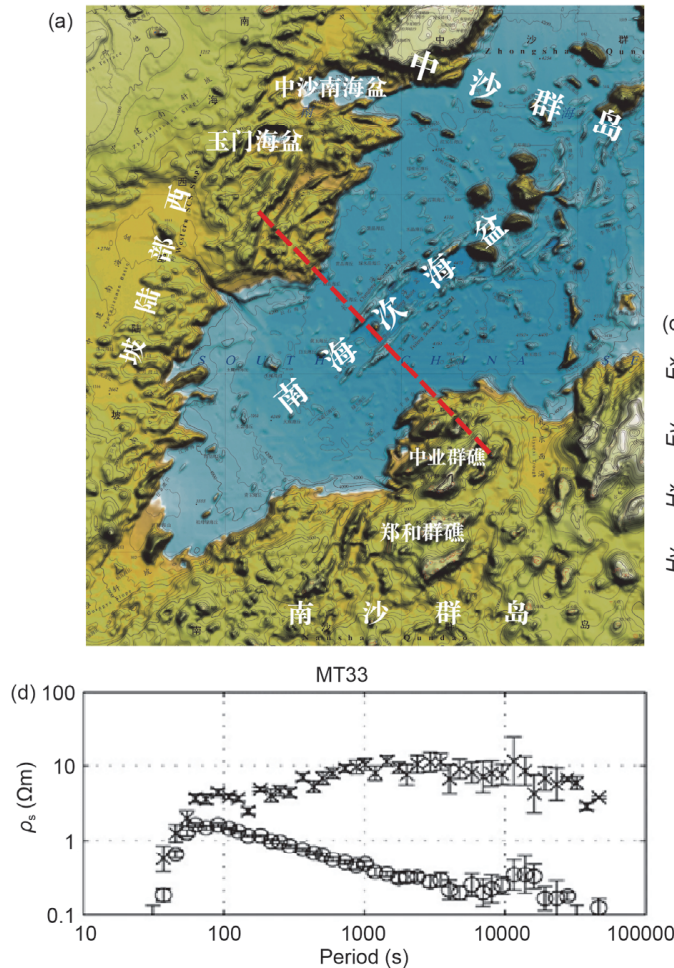
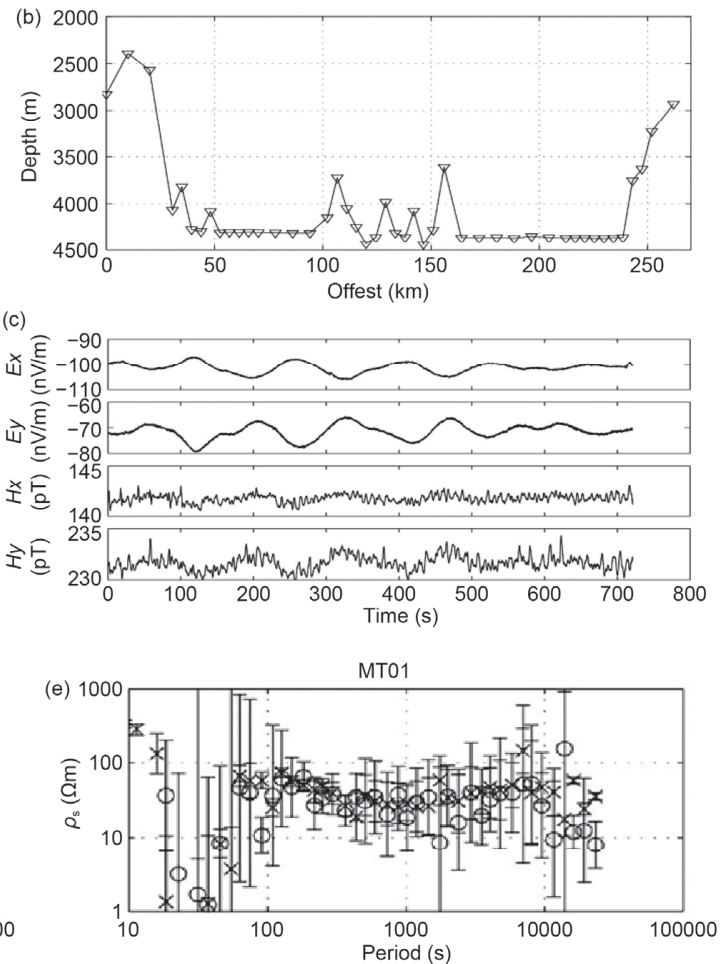

图 1 (网络版彩色)海洋电磁采集工作及野外成果. (a) 剖面位置; (b) 采集站深度及地形; (c) 原始时序曲线; (d) 现场优秀 MT(magnetotelluric method)曲线; (e) 现场最差 MT 曲线

Figure 1 (Color online) Marine electromagnetic acquisition work and field results. (a) Position of profile; (b) depth and topography of profile acquisition; (c) original time series curve; (d) high quality MT curve; (e) worst MT curve 
地电磁调查剖面.

南海是西太平洋最大的边缘海, 经历了岩石圈裂解、 海底扩张到洋壳俯冲等复杂地质过程, 构成了一个从陆到 洋的完整演变旋回, 是研究边缘海形成演化的天然实验 室. 但其破裂模式是否为经典的地幔剥露式破裂一直存在 较大争议. 国外利用海洋大地电磁技术已在莫霍面、洋中 脊、俯冲带等取得了重要发现. 国内陆上大地电磁调查取 得诸多重大成果认识. 开展南海大地电磁探测将有可能揭 示南海古扩张冷破裂演化等重要科学问题. 但由于仪器装 备制约, 在南海电磁探测仍处于起步阶段.

在国家科技支持和科研人员努力下, 直至 2020 年初我 国全面解决了超深水海底极低频电磁信号采集难题, 最低 频率可达20000 s, 磁传感器本底噪声优于 0.1 pT/sqrt(Hz)@ $1 \mathrm{~Hz}$, 电场探头本底噪声优于 $0.1 \mathrm{nV} /(\mathrm{m} \operatorname{sqrt}(\mathrm{Hz})) \mathrm{nV} @ 1 \mathrm{~Hz}$, 具有完全自主产权的OBEM-III仪器系统总体达到国际同等 水平.

本次调查测线跨越平均深度达 $4.3 \mathrm{~km}$ 的西南次海盆 (图1(a)所示位置), 累计实施了 53 个站位(包括重复点7个) 的投放作业, 仪器回收率达 $96.2 \%$. 此次测量所有 46 个坐 标点 36 个测点水深超过 $4000 \mathrm{~m}$, 最深达为 $4443 \mathrm{~m}$ (图 1(b)). 经过对数据分析与预处理, 所有坐标点都获得有效数据, 且有效采集时长均大于 $100 \mathrm{~h}$, 最长达 $232 \mathrm{~h}$, 数据信息完 整(图1(c)), 并依据相关标准评价, 其中 $80 \%$ 以上测点数据 质量达到优良级. 如图 $1(\mathrm{~d})$ 所示, 优良级视电阻率曲线 $\rho_{x y}$ 、 $\rho_{y x}$ 均方相对误差分别是 $5.7 \%$ 和 $8.5 \%$; 如图 1(e)所示, 最差 的视电阻率曲线 $\rho_{x y} 、 \rho_{y x}$ 均方相对误差分别是 $48.6 \%$ 和 $25.4 \%$.

此次首条横跨南海古扩张脊的超深水海洋大地电磁调 查的成功实施, 标志着我国海洋大地电磁仪器研究取得质 的飞跃, 对揭示南海深部岩石圈的电性结构具有里程碑式 的科学意义. 下一步将充分挖掘本次调查数据, 并结合已 有的地震、重磁资料进行联合反演与解释. 广海局计划在 南海开展更多的海底电磁探测工作, 为南海的形成演化研 究提供丰富的科学数据. 